\title{
Factors Influencing ICT Adoption in Some Selected Secondary Schools in Ogun State, Nigeria
}

\author{
https://doi.org/10.3991/ijet.v14i10.10095 \\ Opeyemi P. Ogundile $\left.{ }^{(}\right)$, Sheila A. Bishop, Hilary I. Okagbue \\ Peter O. Ogunniyi, Anuoluwapo M. Olanrewaju \\ Covenant University, Canaanland, Ota, Nigeria \\ opeyemi.ogundile@covenantuniversity.edu.ng
}

\begin{abstract}
This paper addressed the factors affecting ICT adoption in a survey of 300 public and private secondary school students in Ogun state, Nigeria. Likert Scale self- designed questionnaire was the instrument of data collection. Data collected were analysed using frequency, scores, percentage scores, total weighted values and factor analysis. The ungrouped factors obtained using the mean weighted values were grouped into five dimensions using the factor analysis. The research showed that five factors are responsible for ICT adoption as perceived by the students. The factors are: assistance or support factors, availability factors, infrastructure factors, learning tools factors and cognitive factors. These factors can be studied in details and addressed to improve the level of ICT adoption in Nigeria.
\end{abstract}

Keywords-ICT, Academic performance, Likert Scale, Nigeria, KMO, School, Statistics.

\section{Introduction}

Information and Communication Technology (ICT) is a tool that can be applied to all aspects of human endeavour. ICT can be defined as computer-based tools and techniques for gathering and using information. The adoption of ICT in developing countries is often limited because of the cost implications of procurement of IT, lack of maintenance culture in managing ICT facilities, dearth of technical know-how and so on. Over the years, ICT adoption had greatly led to improvement in the workplace, optimization of scarce human and material resources and in achieving given tasks. Several sectors of the economy of Nigeria have adopted ICT as a tool for improving people, processes and procedures. Some are listed; road freight transport [1], construction industry [2], agricultural research [3], small and medium scale enterprises [4-5], accounting systems [6], advertising [7], tourism [8], libraries of tertiary institutions [9-10] and service industry [11]. Others are: school management [12], green technology and renewable energy [13], electronic commerce [14], marketing of pharmaceutical products [15] and effective governance, democracy and elections [16-18]. Other uses can be seen in [19-20]. 
Educational sector is one vital area that applies ICT in teaching and learning [2122] and there is always a need to assess the impact of ICT as a tool for teaching and learning. This will aid the decision makers to assess the impact of ICT against the return on investment (ROI) and the effect of ICT adoption on the academic performance of students.

ICT has been noted to be a viable vehicle that drives economic development. There are uneven distribution of ICT adoption and implementation across Nigeria. The rural areas seem to lag behind the urban centres. In the urban centres, there is also a disparity between ICT adoption in privately and publicly funded schools. ICT adoption is often not viewed as important compared with the enormous problems faced in the educational system in Nigeria in general and secondary schools in particular. Some of the persistent constraints inherent in the educational systems include, but not limited to, the following: poor funding from government, outdated curriculum, red-tapism and official corruption, epileptic power supply, poor working conditions for the teachers, exploitation by private education owners, insecurity in some parts of Nigeria, brain drain, lack of laboratories for practical and cognitive problems [23-24]. All these have snowballed into a steady free fall of the educational sector.

Generally, adoption of ICT is in different phases, some are in the embryonic stage while some schools have successfully incorporated ICT into their curriculum for both privately or publicly funded secondary schools in Nigeria. A survey on ICT adoption on education in Nigeria showed that most research is on the tertiary education [25-27] and very few on secondary education. ICT adoption has shown to be very vital in information dissemination and can assist in quality lecture delivery, effective classroom management, enhanced interactivity and connectivity efficient cognitive testing and can facilitate learning [28-30]. It is also important to note that all the aforementioned benefits of ICT adoption are based on four inter lapping rationale. Firstly, ICT is a tool for getting the students aware of the existence and general use of computers, hardware and software. Secondly, ICT is used as a skill acquisition tool, to prepare the students for employment and entrepreneurship. Thirdly, ICT is adopted to help improve the learning process and lastly, ICT is a tool for improving learning and teaching and administrative processes thereby increasing efficiency and improved academic performance. However, there seems to be dispute on the extent on why ICT can help improve academic performance of students [31].

There is an appreciable improvement on ICT adoption in Nigeria but the success is glacier as some traditional method of chalk and talk are still prevalent in the schools and the effect have led to the students lagging dangerously behind in the trend of changes in the world [32]. Most of the teachers are ICT illiterate and have not received proper training to catch up with the trend of changes in the world.

A look at two papers that discussed about ICT adoption in secondary schools in Nigeria showed the following. The authors were unanimous on the causes of the low level of ICT adoption in secondary schools in Nigeria [33-34]. The causes are low level of interest of the students, lack of maintenance culture, inadequate software, dearth of infrastructural facilities to host and support ICT, power supply failure, nonimplementation of national ICT policy and inadequate policy framework for integrating ICT into the curriculum, the secondary schools are limited in funding and cannot 
attract highly skilled ICT experts, high cost of ICT and recurrent expenditure on their maintenance, poor management and lack of investment in education.

Finally, the two papers considered only publicly funded schools and their teachers, but this research considered both public and private secondary school students. Also, the two papers used mainly descriptive statistics while this paper used factor analysis.

\section{Materials and Methods}

\subsection{Study area and Sampling method}

The data were from a field survey aimed at assessing the factors (variables) influencing ICT adoption by students in four (4) selected secondary schools in Ogun State, Nigeria. The schools comprise of two private and two public schools. Each school have students in both junior and senior levels. The proximity between the schools was the reason for the purposive sampling while simple random sampling was used to recruit the respondents.

A total of 360 questionnaires were distributed and 300 representing $83.3 \%$ was returned and analysed. The data measures the general use of ICT and ICT as a tool for learning and teaching.

\subsection{Questionnaire design}

The questionnaire was divided into two parts, namely, part A and part B. Part A consists of the socio-demographic responses. Part B took contains the measure of the factors influencing the adoption of ICT by secondary school students divided into three parts, namely; general use of ICT, ICT as a tool for learning and ICT as a tool for teaching. Each part consists of five (5) questions which are the variables for measuring the adoption of ICT as a tool that influences academic performance of students in the surveyed schools in particular and Ogun state in general.

\subsection{Statistical method}

The 3-point Likert scale was adopted for proper extraction of the data. and the scores of the responses are presented in Table 1. Thereafter, statistical factor analysis was employed to analyse the data using SPSS 23.0.

Table 1. Likert scale coding for the responses

\begin{tabular}{|l|c|c|}
\hline \multicolumn{1}{|c|}{ Responses } & Key & Scores \\
\hline Strongly agree & SA & 3 points \\
\hline Agree & A & 2 points \\
\hline Disagree & D & 1 point \\
\hline Strongly Disagree & SD & 0 point \\
\hline
\end{tabular}




\section{Results and Discussion}

\subsection{Sociodemographic analysis}

Originally, 360 questionnaires were distributed and 60 were excluded because of nonresponse. The socio-demographic data of the respondents are presented in Tables $2,3,4$ and 5 respectively. They are the age, type of school, gender and level of school of the respondents. It can be seen that $208(69.3 \%)$ of the respondents are between the ages of 11 and 15, $89(29.7 \%)$ are between the ages of 16 and 20 and $3(1 \%)$ are 10 years or below. It can be seen that the respondents were equally drawn from private and public schools. Also, more female (56.3\%) than male (43.7\%) were the final respondents after the removal of the nonresponse data. 140 (46.7\%) of the respondents are in the junior secondary category while $160(53.3 \%)$ are in the senior secondary level.

Table 2. Age of respondents

\begin{tabular}{|c|c|c|c|}
\hline Age & Frequency & Percent & Cumulative Percent \\
\hline$\leq 10$ & 3 & 1.0 & 1.0 \\
\hline $11-15$ & 208 & 69.3 & 70.3 \\
\hline $16-20$ & 89 & 29.7 & 100.0 \\
\hline Total & 300 & 100.0 & \\
\hline
\end{tabular}

Table 3. The type of school of the respondents

\begin{tabular}{|l|c|c|c|}
\hline \multicolumn{1}{|c|}{ School type } & Frequency & Percent & Cumulative Percent \\
\hline Public & 150 & 50.0 & 50.0 \\
\hline Private & 150 & 50.0 & 100.0 \\
\hline Total & 300 & 100.0 & \\
\hline
\end{tabular}

Table 4. Gender of the respondents

\begin{tabular}{|l|c|c|c|}
\hline \multicolumn{1}{|c|}{ Gender } & Frequency & Percent & Cumulative Percent \\
\hline Male & 131 & 43.7 & 43.7 \\
\hline Female & 169 & 56.3 & 100.0 \\
\hline Total & 300 & 100.0 & \\
\hline
\end{tabular}

Table 5. The level of the respondents

\begin{tabular}{|l|c|c|c|}
\hline \multicolumn{1}{|c|}{ Level of school } & Frequency & Percent & Cumulative Percent \\
\hline Junior & 140 & 46.7 & 46.7 \\
\hline Senior & 160 & 53.3 & 100.0 \\
\hline Total & 300 & 100.0 & \\
\hline
\end{tabular}

\subsection{Factors responsible for the ICT adoption}

The Likert scale was used to compute the factors influencing ICT adoption as it relates to the academic performance of the respondents. This is summarised as total 
weighted values (TMV) and mean weighted values (MWV) as shown in Table 6. The data were arranged from the lowest to the highest MWV. Variables with higher MWV are the ones that most influence the ICT adoption and can be perceived as having greater effects on the use of ICT in teaching and learning which consequently affects their academic performance.

Table 6. Factors responsible for the ICT adoption as it affects the academic performance of secondary school students' using the total and mean weighted value

\begin{tabular}{|l|c|c|c|c|c|c|}
\hline \multicolumn{1}{|c|}{ Factors } & \multicolumn{2}{c|}{ Responses } & TWV & MWV \\
\hline Computer Studies & 0 & 1 & 2 & 3 & & \\
\hline Computer Lab & 4 & 20 & 94 & 182 & 754 & 2.51 \\
\hline Communication & 15 & 21 & 111 & 153 & 702 & 2.34 \\
\hline Learning & 16 & 37 & 88 & 163 & 702 & 2.34 \\
\hline Practical & 12 & 37 & 98 & 149 & 680 & 2.27 \\
\hline Google & 20 & 32 & 112 & 136 & 671 & 2.24 \\
\hline Quality & 19 & 44 & 114 & 124 & 641 & 2.21 \\
\hline Retention & 19 & 44 & 128 & 109 & 627 & 2.09 \\
\hline Understanding & 18 & 57 & 105 & 120 & 627 & 2.09 \\
\hline Performance & 18 & 39 & 142 & 101 & 626 & 2.09 \\
\hline Internet & 17 & 56 & 118 & 109 & 619 & 2.06 \\
\hline Teaching Aid & 40 & 62 & 114 & 84 & 542 & 1.81 \\
\hline Frequency & 34 & 80 & 97 & 89 & 541 & 1.8 \\
\hline Usage & 35 & 72 & 116 & 77 & 535 & 1.78 \\
\hline Ability & 121 & 86 & 49 & 44 & 316 & 1.05 \\
\hline
\end{tabular}

The top five ungrouped factors are given as:

- ICT as a tool that aid in the understanding of computer studies

- equipped computer laboratory helps to enhance learning

- ICT helps in communication

- ICT helps in the learning process

- ICT helps students to practise what they are taught in school

On the other hand, the following five factors least affect ICT adoption as perceived by the respondents.

- The internet does not really help. This is not surprising as the chalk and talk method is the traditional norm in this part of the world.

- ICT has not been fully adopted as a teaching aid in Nigeria as seen from the responses from the students.

- The students seem not to be frequent users of ICT in their schools since as the factors mentioned in the introduction section helps explain the reasons why the students are not using ICT more frequently as they ought to.

- ICT usage is still very low.

- Most of the students have not been trained and equipped with the necessary ICT skills that will enable them to be able to use them effectively. 


\section{$4 \quad$ Factor Analysis}

Before factor analysis is applied, Kaiser-Meyer-Olkin (KMO) measure of sampling adequacy and Bartlett's test of sphericity was conducted to determine the applicability of the factor analysis of the raw data. The outcome of the analysis revealed the K.M.O value of 0.822 with Bartlett's test significance level of 0.000 and Chi-square value of 999.409, which is shown in Table 7. This result shows that the survey data is suitable for factor analysis.

Factor analysis was carried out in other to determine the factors that influence ICT adoption as it affects the academic performance of students in secondary schools in Ogun State, Nigeria. Furthermore, the KMO test indicated that the correlation matrix is an identity matrix. Table 8 shows the communality of the variables. The highest and lowest communalities are teaching aids $(76.6 \%)$ and ability $(39.1 \%)$ respectively. The extraction method used is the principal component analysis (PCA) and the total variation explained by the model is shown in Table 9. It can be seen that all factors that are with Eigenvalues above 1 were extracted and represented under the column extraction sums of square loadings. The results revealed 5 unconfirmed factors and also suggested that there was a cumulative total of $56.74 \%$ with variances of $6.81 \%$ and $8.00 \%$ on and after extraction which was confirmed after rotational extraction. Table 10 is the rotated component matrix of factors influencing ICT adoption, obtained using varimax with Kaiser Normalization after 6 iterations. Table 11 is the component transformation matrix and was obtained using PCA as extraction method and varimax with Kaiser Normalization, as rotational method.

$\mathrm{KMO}$ and Bartlett's tests of factors influencing ICT adoption in selected secondary schools in Ogun State, Nigeria.

Table 7. KMO and Bartlett's Test

\begin{tabular}{|l|l|c|}
\hline \multicolumn{2}{|l|}{ Kaiser-Meyer-Olkin Measure of Sampling Adequacy. } & 0.822 \\
\hline \multirow{3}{*}{ Bartlett's Test of Sphericity } & Approx. Chi-Square & 999.409 \\
\cline { 2 - 3 } & Degrees of freedom & 105 \\
\cline { 2 - 3 } & Significance & 0.000 \\
\hline
\end{tabular}

Table 8. Communalities of factors influencing ICT adoption in selected secondary schools in Ogun State, Nigeria

\section{Communalities}

\begin{tabular}{|l|c|c|}
\hline \multicolumn{1}{|c|}{ Factor } & Initial & Extraction \\
\hline Teaching Aid & 1.000 & 0.766 \\
\hline Understanding & 1.000 & 0.710 \\
\hline Learning & 1.000 & 0.658 \\
\hline Frequency & 1.000 & 0.648 \\
\hline Performance & 1.000 & 0.636 \\
\hline Practical & 1.000 & 0.635 \\
\hline Computer Lab & 1.000 & 0.623 \\
\hline Usage & 1.000 & 0.597 \\
\hline
\end{tabular}




\begin{tabular}{|l|l|l|}
\hline Retention & 1.000 & 0.593 \\
\hline Quality & 1.000 & 0.574 \\
\hline Computer Studies & 1.000 & 0.542 \\
\hline Internet & 1.000 & 0.539 \\
\hline Google search & 1.000 & 0.529 \\
\hline Communication & 1.000 & 0.519 \\
\hline Ability & 1.000 & 0.391 \\
\hline
\end{tabular}

Extraction Method: Principal Component Analysis.

Table 9. Total Variance Explained of the factors influencing ICT adoption

\begin{tabular}{|c|c|c|c|c|c|c|c|c|c|}
\hline \multirow[b]{2}{*}{$\begin{array}{r}\text { Com } \\
\text { ponent }\end{array}$} & \multicolumn{3}{|c|}{ Initial Eigenvalues } & \multicolumn{3}{|c|}{$\begin{array}{c}\text { Extraction Sums of Squared } \\
\text { Loadings }\end{array}$} & \multicolumn{3}{|c|}{$\begin{array}{c}\text { Rotation Sums of Squared } \\
\text { Loadings }\end{array}$} \\
\hline & Total & $\begin{array}{l}\text { of of } \\
\text { Vari- } \\
\text { ance }\end{array}$ & $\begin{array}{l}\text { Cumula- } \\
\text { tive \% }\end{array}$ & Total & $\begin{array}{c}\% \text { of } \\
\text { Variance }\end{array}$ & $\begin{array}{l}\text { Cumula- } \\
\text { tive \% }\end{array}$ & Total & $\begin{array}{c}\% \text { of } \\
\text { Variance }\end{array}$ & $\begin{array}{l}\text { Cumula- } \\
\text { tive } \%\end{array}$ \\
\hline 1 & 4.287 & 28.582 & 28.582 & 4.287 & 28.582 & 28.582 & 2.588 & 17.255 & 17.255 \\
\hline 2 & 1.388 & 9.255 & 37.837 & 1.388 & 9.255 & 37.837 & 1.965 & 13.098 & 30.352 \\
\hline 3 & 1.163 & 7.752 & 45.589 & 1.163 & 7.752 & 45.589 & 1.803 & 12.020 & 42.372 \\
\hline 4 & 1.102 & 7.345 & 52.933 & 1.102 & 7.345 & 52.933 & 1.405 & 9.368 & 51.740 \\
\hline 5 & 1.021 & 6.807 & 59.740 & 1.021 & 6.807 & 59.740 & 1.200 & 8.000 & 59.740 \\
\hline 6 & 0.912 & 6.081 & 65.821 & & & & & & \\
\hline 7 & 0.838 & 5.587 & 71.407 & & & & & & \\
\hline 8 & 0.744 & 4.963 & 76.371 & & & & & & \\
\hline 9 & 0.658 & 4.385 & 80.755 & & & & & & \\
\hline 10 & 0.599 & 3.996 & 84.752 & & & & & & \\
\hline 11 & 0.547 & 3.649 & 88.401 & & & & & & \\
\hline 12 & 0.492 & 3.282 & 91.683 & & & & & & \\
\hline 13 & 0.478 & 3.186 & 94.869 & & & & & & \\
\hline 14 & 0.417 & 2.780 & 97.649 & & & & & & \\
\hline 15 & 0.353 & 2.351 & 100.000 & & & & & & \\
\hline
\end{tabular}

Extraction Method: Principal Component Analysis.

Table 10. Rotated Component Matrix of Factors Influencing ICT adoption in Nigeria for secondary school students

Rotated Component Matrix ${ }^{a}$

\begin{tabular}{|l|c|c|c|c|c|}
\hline \multirow{2}{*}{} & \multicolumn{5}{|c|}{ Component } \\
\cline { 2 - 6 } & $\mathbf{1}$ & $\mathbf{2}$ & $\mathbf{3}$ & $\mathbf{4}$ & $\mathbf{5}$ \\
\hline Understanding & 0.784 & & & & \\
Quality & 0.683 & & & & \\
Internet & 0.648 & & & & \\
Performance & 0.636 & & & & \\
Google search & 0.538 & & & & \\
\hline Frequency & & 0.737 & & & \\
Usage & & 0.726 & & & \\
Communication & & 0.659 & & & \\
\hline
\end{tabular}




\begin{tabular}{|l|l|l|l|l|l|}
\hline Learning & & & 0.748 & & \\
Computer Lab & & & 0.715 \\
Computer Studies & & & & \\
\hline Teaching Aid & & & & 0.453 & \\
Practical & & & & & \\
\hline Retention & & & & 0.634 & \\
Ability & & & & & 0.634 \\
\hline
\end{tabular}

Extraction Method: Principal Component Analysis. Rotation Method: Varimax with Kaiser Normalization. ${ }^{\text {a }}$

a. Rotation converged in 6 iterations.

Table 11. Component transformation matrix of Factors Influencing Students' Perception of Academic Performance

Component Transformation Matrix

\begin{tabular}{|c|c|c|c|c|c|}
\hline Component & $\mathbf{1}$ & $\mathbf{2}$ & $\mathbf{3}$ & $\mathbf{4}$ & $\mathbf{5}$ \\
\hline 1 & 0.682 & 0.495 & 0.443 & 0.286 & -0.110 \\
\hline 2 & 0.155 & -0.622 & 0.391 & 0.324 & 0.575 \\
\hline 3 & -0.340 & 0.121 & 0.752 & -0.551 & 0.022 \\
\hline 4 & 0.509 & 0.036 & -0.278 & -0.666 & 0.467 \\
\hline 5 & -0.368 & 0.593 & -0.095 & 0.255 & 0.662 \\
\hline
\end{tabular}

Extraction Method: Principal Component Analysis.

Rotation Method: Varimax with Kaiser Normalization.

\subsection{Variables explanation}

The key summary of the factor analysis is Rotated Component Matrix (Table 10). It could be seen there that the 15 factors (variables) are divided into five major groups (dimensions). They are:

- a) Assistance or Support factors: These are factors that mostly motivate the students in the adoption of ICT. Here, the students believe that ICT helps them in understanding their assignments, improving the quality of their assignments/term papers/research, the use of internet helps them in their assignments, ICT helps them to improve their performance in school and google search engine helps or assist them in doing their assignments.

- b) Availability factors: These are factors that when improved can help the students. They include increasing the access to ICT so that students can use them frequently to communicate with their peers, colleagues and teachers.

- c) Infrastructure factors: These are factors that must be needed to host ICT such as computer laboratory, power supply and conducive environment for learning.

- d) Learning tools factors: These are factors that help effective learning to take place. These include teaching aids and practical to put to practice the lecture that was taught in the classroom.

- e) Cognitive factors: These are factors that help students to understand, assimilate, retain and apply the knowledge taught using the available ICT tools. 
The five major factors are key determinants to effective ICT adoption in Nigeria that can facilitate effective learning [35-39]. However, government and top management of schools [40] are required to drive the ICT adoption by development of policies [41] and strategies for implementation [42-43].

\section{Conclusion}

The paper has identified five key factors that affect ICT adoption in the private and public secondary schools in Nigeria. The factors were obtained from the analysis of data using factor analysis. ICT adoption in Nigeria will be improved if the identified factors are studied deeply and addressed using appropriate policies, procedures and strategies. Nigerian schools cannot afford to continually lag behind other countries in areas of ICT and computer usage. The purposeful and continuous adoption of ICT in Nigeria will help to properly prepare the students for employment and entrepreneurship, thereby reducing unemployment and Fastrack the nation quest to achieve Millennium sustainable goals.

\section{Acknowledgement}

The sponsorship received from Covenant University through Covenant University Centre for Research, Innovation and Discovery is greatly appreciated.

\section{$7 \quad$ References}

[1] Tob-Ogu, A., Kumar, N., \& Cullen, J. (2018). ICT adoption in road freight transport in Nigeria-A case study of the petroleum downstream sector. Tech. Forec. Soc. Change, 131, 240-252. https://doi.org/10.1016/j.techfore.2017.09.021

[2] Amusan, L. M., Oloniju L. I., Mariam, A., Adebisi, M., Farayola Hezekiah, N.-P.P. \& Osawaru, F. (2018). Adopting information and communication technology in construction industry. Int. J. Mech. Eng. Tech., 9 (1), 739-746.

[3] Adesiji, G. B., Ibrahim, M. \& Komolafe, S. E. (2017). Comparative assessment of agricultural technology generating practices in universities and research institutes in north central zone of Nigeria. Info. Process. Agric., 4 (2), 161-167.https://doi.org/10.1016/j.inpa. 2017.03.004

[4] Hassan, H. \& Ogundipe, A. A. (2017). ICT adoption by micro and small scale enterprises in Nigeria: A case study of the Federal Capital Territory, Abuja. Int. J. Econ. Research, 14 (18), 117-137. https://doi.org/10.2139/ssrn.2951901

[5] Taiwo Agwu, J. N., Mercy, A. \& Evawere, A. (2016). The role of ICTS in the improvement of the competitiveness of SMEs. Asian J. Info. Tech., 15 (18), 3414-3421.

[6] Ogundana, O. M., Okere, W., Ayomoto, O., Adesanmi, D., Ibidunni, S. \& Ogunleye, O. (2017). ICT and accounting system of SMEs in Nigeria. Management Sci. Lett., 7, 1-8. https://doi.org/10.5267/j.msl.2016.11.007

[7] Adigun, A. O. \& Akinbinu, T. S. (2017). The impact of ICT usage in improving advertising strategies in selected media house: A case study of Splash FM (105.5). Libr. Phil. Pract., 2017 (1), Article number 1516. 
[8] Eweoya, I. O., Okuboyejo, S. R. \& Kelechi, A. (2016). The adoption of E-tourism: An empirical investigation. Asian J. Info. Tech., 15 (18), 3422-3429.

[9] Idiegbeyan-Ose, J., Ifijeh, G., Adebayo, O. \& Segun-Adeniran, C. (2016). New paradigms in cataloguing in the 21st century: A review of implications and adoption of new strategies for Nigerian libraries. Bilgi Dunyasi, 17 (1), 120-134.https://doi.org/10.15612/bd.2016.500

[10] Idiegbeyan-Ose, J., Nkiko, C., Idahosa, M. \& Nwokocha, N. (2016). Digital divide: Issues and strategies for intervention in Nigerian libraries. J. Cases Info. Tech., 18 (3), 29-39. https://doi.org/10.4018/icit.2016070103

[11] Ekuobase, G. O. \& Olutayo, V. A. (2016). Study of Information and Communication Technology (ICT) maturity and value: The relationship. Egypt. Informat. J., 17 (3), 239249. https://doi.org/10.1016/j.eij.2015.12.001

[12] Omotayo, F. O. \& Chigbundu, M. C. (2017). Use of information and communication technologies for administration and management of schools in Nigeria. J. Syst. Info. Tech., 19 (3-4), 183-201. https://doi.org/10.1108/jsit-06-2017-0045

[13] Alkali, A. U., Abdul-Azeez, I. A., Mansor, M. N. A., Chikaji, A. I. \& Dodo, Y. A. (2017). Towards low carbon universities in Nigeria: Agenda for green information technology. Chem. Engine. Transac., 56, 733-738.

[14] Awa, H. O., Awara, N. F. \& Lebari, E. D. (2015). Critical factors inhibiting electronic commerce (EC) adoption in Nigeria: A study of operators of SMEs. J. Sci. Tech. Policy Magt., 6 (2),143-164. https://doi.org/10.1108/jstpm-07-2014-0033

[15] Aderemi, H. O., Ojediran, I. A., Adegbite, S. A. \& Olasanmi, O. O. (2015). Effects of the use of ICT on pharmaceutical product marketing in Nigeria. Int. J. Magt. Bus. Res., 5 (4), 315-327.

[16] Duruji, M., Ayo, C. K., Gberevbie, D. E. \& Oluranti, J. (2015). The impact of eDemocracy in political stability of Nigeria. Proc. Euro. Conf. e-Govt., 93-99.

[17] Oni, A., Ayo, C. K., Oni, S. \& Duruji, M. (2015). Electronic petition and democratic participation in Nigeria. Proc. Euro. Conf. e-Govt., (223-230.

[18] Gberevbie, D. E., Ayo, C. K., Iyoha, F., Duruji, M. \& Abasilim, U. (2015). E-Governance: Strategy for mitigating non-inclusion of citizens in policy making in Nigeria. Proc. Euro. Conf. e-Govt., 117-124. https://doi.org/10.1504/ijeg.2018.091266

[19] Akinola, A. O., Salau, T., Oluwatayo, A., Babalola, O. \& Okagbue, H. I. (2018). Data on the awareness and adoption of ICT in town planning firms in Lagos state, Nigeria. Data in Brief, 20, 436-447. https://doi.org/10.1016/j.dib.2018.08.036

[20] Oguntunde, P. E., Okagbue, H. I., Oguntunde, O. A., Opanuga, A. A. \& Oluwatunde, S. J. (2018). Analysis of the inter-relationship between students' first year results and their final graduating grades. International Journal of Advanced and Applied Sciences, 5(10), 1-6. https://doi.org/10.1016/j.dib.2018.03.096

[21] Shu'aibu, B., Saud, M. S., Bello, H., Kamin, Y. \& Buntat, Y. (2013). Modelling the Determinants of ICTs Policy Formulation in Technical and Vocational Education in Nigerian Institution of Higher learning. Indian J. Sci. Tech., 6 (4), 4273-4381.

[22] Sofowora, O. A. (2012). An assessment of the extent of integration, application and utilization of web-based learning systems in post basic institutions in Nigeria. Asian Soc. Sci., 8 (3), 317-320. https://doi.org/10.5539/ass.v8n3p317

[23] Bishop, S. A., Owoloko, E. A., Okagbue, H. I., Oguntunde, P. E., Odetunmibi, O. A. \& Opanuga, A. A. (2017). Survey datasets on the externalizing behaviors of primary school pupils and secondary school students in some selected schools in Ogun State, Nigeria. Data in Brief, 13, 469-479. https://doi.org/10.1016/j.dib.2017.06.025

[24] Bishop, S. A., Okagbue, H. I., Oludayo, O. A., Agboola, O. O., Agarana, M. C. \& Adamu, M. O. (2018). Survey dataset on the types, prevalence and causes of deviant behavior 
among secondary school adolescents in some selected schools in Benin City, Edo State, Nigeria. Data in Brief, 20, 101-107. https://doi.org/10.1016/j.dib.2018.07.059

[25] Bakare, A. A. \& Olaniyi, E. T. (2017). Use and Application of ICT in Teaching and Learning for Quality Higher Education in Nigeria: A Literature Analysis. Greener J. Educ. Research, 7(2), 15-20.

[26] Ibrahim, A. M., Hassan, M. S. H., Gujbawu M., \& Khoshrouzadeh, J. (2018). Influence of ICT Adoption on Tertiary Education: Investigating ICT Usage in E-learning Context among Nigerian Students. J. Educ. Practice, 9(16), 21-34.

[27] Hamilton-Ekeke, J.T. \& Mbachu, C. E. (2015). The Place of Information, Communication and Technology (ICT) in Teaching and Learning in Nigerian Tertiary Institutions. Amer. J. Educ. Res., 3 (3), 340-347.

[28] Olaore, I. B. (2014). The Impacts (Positive and Negative) of ICT on Education in Nigeria. Developing Country Studies, 4(23), 154-156.

[29] Toyo, O. D. (2017). Information and Communication Technology (ICT) Adoption and the Educational Growth of Colleges of Education in Agbor and Warri, Delta State, Nigeria Constraints of ICT adoption. Int. J. Educ. Eval., 3 (7), 19-32.

[30] Yusuf, M. A., Afolabi, F. O. \& Loto, A. B. (2013). Appraising the role of information communication technology (ICT) as a change agent for higher education in Nigeria. Int. J. Educ. Admin. Policy Studies, 5(8), 177-183.

[31] Odeniyi, O. A., Ayinde, A. Q., Adetunji, A. B. \& Sarumi, O. A. (2013). Adoption of ICT to enhance educational development In Nigeria. IJCSI Int. J. Comp. Sci. Issues, 10, 4, $27-$ 31.

[32] Okebukola P (1997). Old, new and current technology in education. UNESCO Africa. 14(15), 7-18.

[33] Ajayi, I. A. \& Ekundayo, H. T. (2009). The application of information and communication technology in Nigerian secondary schools. International NGO Journal, 4 (5), 281-286.

[34] Adomi, E. E. \& Kpangban, E. (2010). Application of ICTs in Nigerian Secondary Schools. Library Philosophy and Practice, Article 345.

[35] Mohammad, M., Ghazali, N. \& Hashim, H. (2018). Secondary school students' perceptions on the use of Google+ towards improving ESL writing skills. International Journal of Emerging Technologies in Learning,13 (9), 224-238.https://doi.org/10.3991/ijet. v13i09.8479

[36] Li, C. (2018). Intelligent system for college English listening and writing training. International Journal of Emerging Technologies in Learning, 13 (10), 121-133.

[37] Naveed, Q. N., Muhammed, A., Sanober, S., Qureshi, M. R. N. \& Shah, A. (2017). Barriers effecting successful implementation of E-learning in Saudi Arabian Universities. International Journal of Emerging Technologies in Learning, 12, (6), 94-107. https://doi.org/ 10.3991/ijet.v12i06.7003

[38] Raso, D., Tungkunanan, P. \& Anukulwech, A. (2017). Factors supporting an information technology management: Teachers in primary schools in Thailand. International Journal of Emerging Technologies in Learning, 12 (4), 126-140. https://doi.org/10.3991/ijet.v12i04. $\underline{6654}$

[39] Romi, I. M. (2017). A model for e-learning systems successes: Systems, determinants, and performance. International Journal of Emerging Technologies in Learning, 12 (10), 4-20.

[40] Kashada, A., Li, H. \& Koshadah, O. (2018). Analysis approach to identify factors influence digital learning technology adoption and utilization in developing countries. International Journal of Emerging Technologies in Learning, 13 (2), 48-59. https://doi.org/10.39 91/ijet.v13i02.7399 
[41] Matar, N. (2017). Defining E-learning level of use in Jordanian Universities using CBAM framework. International Journal of Emerging Technologies in Learning, 12 (3), 142-153. https://doi.org/10.3991/ijet.v12i03.6497

[42] Sosa, E., Salinas, J. \& Crosetti, B. B. (2018). Model of incorporation of emerging technologies in the classroom (MIETC). International Journal of Emerging Technologies in Learning, 13 (6), 124-148. https://doi.org/10.3991/ijet.v13i06.8226

[43] Solangi, Z. A., Al Shahrani, F. \& Pandhiani, S. M. (2018). Factors affecting successful implementation of eLearning: Study of colleges and institutes sector RCJ Saudi Arabia. International Journal of Emerging Technologies in Learning, 13 (6), 223-230. https://doi.org/10.3991/ijet.v13i06.8537

\section{Authors}

Opeyemi P Ogundile received his B.Sc from Covenant University in Nigeria and proceeded to the prestigious university of Ibadan, Nigeria for his Master's in Mathematics. He is currently a faculty member at Covenant university, Nigeria and his areas of interest are Financial Mathematics, Mathematical Modeling, Stochastic (numerical) Differential Equation and Statistics

Sheila A Bishop holds N.C.E. Mathematics/Physics, B.Sc(Ed) Mathematics, M.Sc Mathematics and Ph.D degrees in Mathematics from the College of Education Benin, University of Benin, University of Ibadan and Covenant University respectively. She is a faculty in the Department of Mathematics, Covenant University, Nigeria. She has served in various committees at the Departmental, College and University levels from 2007 to date. She is currently the acting head of the Department of Mathematics, Covenant University, Nigeria. She has a teaching experience of over (2) decades in both public and private schools. She has supervised over ten (10) undergraduate students and currently supervising two (2) post graduate students. She has also served as examiner to several $\mathrm{PhD}$ thesis and a reviewer to some journals. She is a Mathematician with research interest in quantum stochastic differential equations, stochastic differential equations, ordinary differential equations, Mathematical Statistics. Some of her research activities in differential equations cover both qualitative and quantitative analysis of solutions. She also has interest in Mathematics education and Mathematical Physics.

Hilary I Okagbue Obtained his B.Tech and M.Sc degrees in Industrial Mathematics and Statistics from the Federal University of Technology, Owerri and University of Lagos in 2007 and 2010 respectively. He is currently on a Ph.D programme at Covenant University, Ota, Nigeria where he works as a researcher and Lecturer at the department of Mathematics. His research interests include: Data analysis, Mathematical Statistics, Mathematical Cryptography and analysis of patterns in number theory.

Peter O Ogunniyi holds Bachelor's degree of technology (B.tech) in Pure and Applied Mathematics from Ladoke Akintola University of Technology (LAUTECH) Ogbomoso in 2008; Masters of Science from Covenant University, Ota in 2012 and currently working on his $\mathrm{PhD}$ in the same university.

Anuoluwapo M Olanrewaju obtained a B.Tech. degree from Ladoke Akintola University of Technology where she studied Pure and Applied Mathematics. She then 
Proceeded to Cape Peninsula University of Technology, Cape Town, South Africa and obtained her M. Tech. degree in Applied Mathematics (Fluid dynamics) awarded by the Department of Mechanical Engineering of the Institution. On her return back to Nigeria, she went back to Ladoke Akintola University of Technology and obtained an MBA (Financial Management) after which she proceeded to the University of Ilorin for her $\mathrm{Ph} . \mathrm{D}$ in Mathematics (Fluid dynamics). She has a number of publications both local and international.

Article submitted 2019-01-05. Resubmitted 2019-03-09. Final acceptance 2019-03-14. Final version published as submitted by the authors. 